\title{
Promising method for determining the concentration of nano-sized diamond powders in water suspensions
}

\author{
H.V.Dorozinska ${ }^{1}$, G.V.Dorozinsky ${ }^{2}$, V.P.Maslov ${ }^{2}$ \\ ${ }^{1}$ Lashkaryov Institute of Semiconductor Physics, National Academy of \\ Sciences of Ukraine, 41 Nauky Pr., 03028 Kyiv, Ukraine \\ ${ }^{2}$ National Technical University of Ukraine "Igor Sikorsky Kyiv \\ Polytechnic Institute", 37 Peremogy Ave., 03056 Kyiv, Ukraine
}

Received June 20, 2017

\begin{abstract}
This work is devoted to investigation of water suspension of synthetic diamond powders with sizes of particles smaller than one micrometer, which is used in processing the materials of parts of optical and electronic devices. It has been shown the influence of various concentrations of diamond powders in distilled water on the response value of the sensor based on surface plasmon resonance (SPR) phenomenon. For comparison, there are performed investigations using the conductometric method. Experimental results show high sensitivity of the SPR method $\left(840 \mathrm{ang}\right.$. $\left.\min \cdot \mu \mathrm{g}^{-1} \cdot \mathrm{ml}\right)$ to the low concentrations of the powder from 2 up to $50 \mu \mathrm{g} / \mathrm{ml}$. The conductometric method is spurious. Experimental results are in a good agreement with the suspension model based on the approaches by Maxwell-Garnett and mathematical formalism of Jones scattering matrices (relative error of measurement results is no more than $5 \%$ ). The obtained results can be useful in applications for technological processes in enterprises of optical and electronic industry.

Keywords: diamond powders, water suspensions, concentration determination, surface plasmon resonance, conductivity.
\end{abstract}

Исследована водная суспензия синтетических алмазных порошков с размерами частиц менее микрона, которая используется при обработке материалов деталей оптических и электронных приборов. Показано влияние различных концентраций алмазных порошков в дистиллированной воде на величину отклика сенсора на основе явления поверхностного плазмонного резонанса (ППР). Для сравнения параллельно проводились исследования кондуктометрическим методом. Показана высокая чувствительность метода ППР (840 угл. мин·мк $\left.\Gamma^{-1} \cdot \mathrm{M}\right)$ к малым концентрациям порошка от 2 до 50 мкг/мл. Кондуктометрический метод оказался неинформативным. Экспериментальные результаты хорошо согласуются с математической моделью суспензии на основе подхода Максвелла-Гарнетта и математического формализма матриц рассеяния Джонса (относительная погрешность результата измерения 5 \%). Результаты исследования могут быть полезны для использования в технологических процессах на предприятиях оптической и электронной промышленности.

Перспективний метод визначення концентрації нанорозмірних алмазних порошків у водних суспензіях. Г.В. Дорожинська, Г.В.Дорожинський, В.П.Маслов.

Досліджено водну суспензію синтетичних алмазних порошків із розмірами частинок менше мікрона, яка використовується при обробці матеріалів деталей оптичних $\mathrm{i}$ електронних приладів. Показано вплив різних концентрацій алмазних порошків у дистильованій воді на величину відгуку сенсора на основі явища поверхневого плазмонного резонансу (ППР). Для порівняння паралельно проводилися дослідження кон- 
дуктометричним методом. Показано високу чутливість методу ППР (840 кут. хв·мкг $\left.{ }^{-1} \cdot \mathrm{мл}\right)$ до малих концентрацій порошку від 2 до 50 мкг/мл. Кондуктометричний метод виявився неінформативним. Експериментальні результати добре узгоджуються з математичною моделлю суспензії на основі підходу Максвелла-Гарнетта і математичного формалізму матриць розсіювання Джонса (відносна похибка результату вимірювання 5 \%). Результати дослідження можуть бути корисні для використання у технологічних процесах на підприємствах оптичної та електронної промисловості.

\section{Introduction}

Enhancement of productivity in surfaces precision polishing of opto-electronic elements can be provided only when using the new compositions of suspensions consisting of abrasive powders and colloidal systems containing nanoparticles. Optimization of characteristics of such systems (dispersion, concentration) is a topical task [1]. Due to its exclusive hardness and cutting capability, diamond became the most efficient abrasive material in grinding and polishing the precision parts. Application of diamonds as nanoparticles in the colloidal systems aimed at polishing is caused by their high hardness, chemical durability and high heat conductivity [2]. To provide precision processing of surfaces, it is necessary to use stable water suspensions with minimal sizes of aggregates and the maximal specific surface [3]. Due to a great amount of functional surface groups, the nanosized diamonds are inclined to form aggregates of primary and secondary kinds, which lower stability of the suspensions [4]. With increasing the number of particles in the suspensions, the quantity of contacts between them increases, too, which can cause formation of bonds between the primary aggregates, and these bonds can provoke worsening the sedimentation stability. The unsteady suspension is inapplicable in using for mechanical processing [5]. Therefore, it is purposeful to apply the suspensions with a minimal concentration of nanoparticles in the unit volume.

The available methods for controlling the concentration and dispersion of the suspensions allow determining the sizes of nanoparticles and their size dispersion [6, 7]. Of the most practical applicability are the methods for the dispersion control based on measurements of light scattering, using optical and electron microscopy, ultrasonic and electroacoustic spectrometry, nuclear magnetic resonance and some others. Majority of them are of lab type and need considerable time expenses as well as preparation of samples for analysis [8].

To determine the concentration of the colloidal solutions, methods of photometry, microscopy and method of suspension dehydration are usually used. But these methods possess essential deficiencies, namely: low sensitivity and accuracy of measurements, and dehydration procedure requires destruction of the suspension.

Therefore, it seems necessary to develop an alternative method for determining the low concentrations of particles in water suspensions. As this method for studying the water suspensions, we chose the optical one based on the phenomenon of surface plasmon resonance (SPR). Diagnostic facilities operating due to this phenomenon possess very high sensitivity to the low concentrations $(0.01-2 \mathrm{ng} / \mathrm{ml})[9,10]$ in studied liquid and gas-like substances, high accuracy of measurement results [11,12] and are mainly applied in medicine [13].

The aim of this work is to investigate possibilities of controlling the low concentrations of diamond powders in distilled water with high sensitivity and productivity by using the SPR method.

\section{Experimental}

2.1. Model of the effective medium that describes concentration of a solid-phase finedispersed filler in a heterostructural matrix

To determine concentration of nano-diamond powder in water suspension, we apply the model of heterostructure. This heterostructure consists of a liquid matrix and a solid-phase fine-dispersed filler. When the values of relative permittivity for the matrix and filler are known, the model enables to determine the composition percentage for this heterostructure. As a matrix, we considered distilled water, and as a filler nano-sized diamond powder. When describing this system, the most widely used are techniques based on the Wiener limits, Maxwell-Garnett and Bruggeman approaches. When using this model, it is introduced the conception of "effective medium" with the effective dielectric permittivity, the value of which lies between the values of dielectric permittivities inherent to the matrix and filler.

The Wiener limits [14] describe boundary values of the relative effective dielectric 
permittivity in the model of a the layered structure [15]. As diamond powder nanoparticles in water suspension are distributed chaotically, this approach is applicable only to determine the range of possible values for the effective permittivity of this suspension. More efficient approaches are those by the Maxwell-Garnett and Bruggeman that successfully describe media with chaotic distribution of filler in the matrix. The main condition for applicability of the Maxwell-Garnett approach [16] is small size $a$ of the nanoparticles as compared with the distance between them $b$, and, as a consequence, their low volume concentration $f$ in the main mass of substance (Fig. 1).

Medium within the framework of the Maxwell-Garnett model possesses dielectric permittivity that is related with permittivities of components by Exp. (1). The model based on the Bruggeman approach [17] is valid in the case when volume fractions of the components $f_{1}$ and $f_{2}$ correspond to the values lying between $1 / 3$ and $2 / 3$, i.e., when the concentrations are sufficiently high

$$
\frac{\varepsilon-\varepsilon_{2}}{\varepsilon-2 \varepsilon_{2}}=f \frac{\varepsilon_{1}-\varepsilon_{2}}{\varepsilon_{1}-2 \varepsilon_{2}},
$$

where $f$ is volume fraction of nanoparticles in suspension; $\varepsilon$ is relative dielectric permittivity of suspension; $\varepsilon_{1}$ and $\varepsilon_{2}$ are relative dielectric permittivities of nanoparticles and matrix substances, respectively.

As in accord with the set task it is necessary to control low concentrations of diamond powders in distilled water by using the SPR method, we applied the MaxwellGarnett method for this modeling.

As initial data for this modeling, we used relative dielectric permittivities inherent to water and diamond at the respective wavelength. For the SPR method, the wavelength $650 \mathrm{~nm}$ is usually considered as an optimal one, from the viewpoint of reaching the maximum sensitivity [18]. However, electromagnetic radiation in the infrared range is characterized by an enhanced thermal influence on the studied sample, which causes its heating and, as a consequence, increase in the absolute temperature error in the measurement results.

Therefore, it seems purposeful to perform measurements by using the wavelengths from the visible range, which can be provided by commercial lasers operating, for instance, at wavelength of $650 \mathrm{~nm}$. At this wavelength, the relative dielectric per-

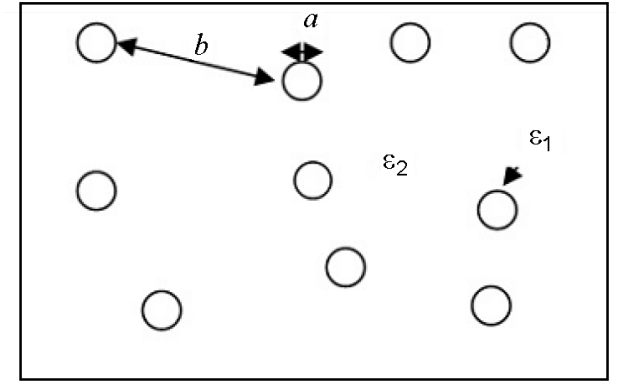

Fig. 1. Model of composite considered within the frames of Maxwell-Garnett and Bruggeman approaches [15].

mittivities of distilled water and diamond are 1.7726 and 5.8047, respectively [19, 20].

Estimation of the SPR sensor response, i.e., the angular shift of the reflection characteristic minimum $R(\theta)$, was performed by plotting the theoretical curve $R(\theta)$ for a the multilayer system "prism (glass) - metal layer - dielectric (analyte) - ambient medium" illuminated with $p$-polarized monochromatic incident radiation for the following analytes: distilled water and the water - diamond suspension. In this system, the prism provides necessary conditions for SPR observation: total internal reflection at the boundary of metal layer - analyte. Near the surface of the metal layer with the optimal thickness of $50 \mathrm{~nm}$, surface plasmons are excited by $p$-polarized monochromatic light with the wavelength of $650 \mathrm{~nm}$ [21, 22]. For modeling, as a material of the metal layer we chose gold, since it provides the least half-width of the reflection characteristic due to its high conductivity (however, this half width is a little wider than that of silver. Besides, silver is quickly oxidized in water and, therefore, used in the SPR sensors for analyzing only air compositions).

The reflection characteristics $R(\theta)$ are calculated as functions of the angle of incidence by using the Fresnel formulae and mathematical formalism of the Jones scattering matrixes [15] and the method described in [23]. The sensor response is determined as a difference between the values of angular positions for the reflection characteristics minima of distilled water and respective suspension.

\subsection{Materials and measuring equipment}

We performed measurements of the angular shift inherent to the reflection characteristics of 7 samples of water - dia- 
Table 1. Technical performances of SPR-refractometer "Plasmon-6"

\begin{tabular}{||c|c|c||}
\hline Performances & $\begin{array}{c}\text { Unit of } \\
\text { measurement }\end{array}$ & $\begin{array}{c}\text { Value of } \\
\text { parameter }\end{array}$ \\
\hline \hline $\begin{array}{c}\text { Range of angle } \\
\text { measurements }\end{array}$ & ang. deg. & $38-70$ \\
Angular resolution & ang. sec. & \pm 3 \\
Maximum angle \\
of scanning \\
$\begin{array}{c}\text { Time for measuring } \\
\text { reflection characteristic } \\
\text { Minimal time for one } \\
\text { measurement: }\end{array}$ & ang. deg. & 17 \\
$\begin{array}{c}\text { in the Multiple mode } \\
\text { in the Slope mode } \\
\text { Number of optical } \\
\text { channels }\end{array}$ & $\mathrm{s}$ & $\leq 3$ \\
\hline
\end{tabular}

mond powder suspensions with various concentrations of diamond nanoparticles, namely: $2.5,5,10,20,30,40$ and $50 \mu \mathrm{g} / \mathrm{ml}$ (ppm). The mean size of the particles was smaller than one micrometer. In addition, we carried out measurements by using the conductometric method for determination of specific conductivity for each suspension. Our experimental facility consisted of SPRrefractometer "Plasmon-6", a peristaltic pump and thermostat developed in V.Lashkaryov Institute of Semiconductor Physics of the NAS of Ukraine. The main technical performances of this refractometer are summarized in Table 1.

The operation surface of a sensitive element in the SPR refractometer consists of a gold layer with the thickness of $50 \pm 2 \mathrm{~nm}$ deposited on a substrate made of optical glass F1. Surface plasmons are excited in this layer by $p$-polarized light from a semiconductor injection laser diode emitting the wavelength of $650 \mathrm{~nm}$. The necessary conditions for excitation of the surface plasmons are provided by varying the angle of light incidence onto the surface of the sensitive element.

Angular dependence of intensity of light reflected from the sensitive element surface $R(\theta)$ is the main initial characteristic of the device. To provide real-time determination of the angular shift of minimum inherent to the reflection characteristic, when distilled water is substituted with suspension samples, there foreseen are two modes of operation in this device: Multiple and Slope [18].
In the Multiple mode that was chosen for these experiments, we performed periodical measurements of $R(\theta)$ characteristic to determine the angular shift of its minimum $\Delta \theta$. The measured characteristics minimum was approximated by the polynomial of the second power to reduce the measurements error caused by a finite step of angular scanning when measuring this characteristic. Then, we determined the angular position of the minimum inherent to the approximating polynomial $\theta_{\text {min }}$, which is related with the measurement results.

The SPR refractometer, pump and reservoirs with suspension samples were placed into the thermostat and kept at temperature of $20^{\circ} \mathrm{C}$. When measuring the conductance, the conductometer and reservoirs with the samples were also placed into the thermostat at the same temperature. Step-by-step substitution of water with suspensions in the device measuring cell was carried out using the peristaltic pump. The analytes were pumped through measuring cell with velocity of about $50 \pm 1 \mu \mathrm{l} / \mathrm{min}$. The volume of this cell with input pipes was $50 \mu \mathrm{l}$, which provides performing the express analysis (no longer than $2 \mathrm{~min}$ ).

Measurements with the conductometer were aimed to show the advantages of the SPR method. Instrumental errors of the measurements with the conductometer EZ-1 and SPR refractometer "Plasmon-6" were respectively $\pm 1 \mu \mathrm{Sm} / \mathrm{cm}$ and \pm 3 ang. sec. For each studied sample, we performed the series of 10 sequential measurements to reduce the methodical error in the measurement results.

\section{Results and discussion}

The values of measured angular shift for the minimum of reflection characteristic, concentrations of the set and calculated using the Maxwell-Garnett model as well as specific conductance of the studied water suspension samples of nano-sized diamond powder are summarized in Table 2. Indicated in the parentheses is the calculated concentration with account of the correction described below.

The data in Table 2 clearly show that the conductometric method of measurements is not informative and, consequently, cannot be used for determination of the low concentrations of indissoluble impurities in liquids.

The plot of dependence inherent to the measured angular shift of the reflection characteristic minimum on concentration of the 
Table 2. Results of measurements and calculations

\begin{tabular}{|c|c|c|c|c||}
\hline $\begin{array}{c}\text { No of } \\
\text { exp. }\end{array}$ & $\begin{array}{c}\text { Set concentration, } \\
\mu \mathrm{g} / \mathrm{ml}\end{array}$ & $\begin{array}{c}\text { Response of the SPR } \\
\text { sensor, ang. sec. }\end{array}$ & $\begin{array}{c}\text { Calculated } \\
\text { concentration, } \mu \mathrm{g} / \mathrm{ml}\end{array}$ & $\begin{array}{c}\text { Measured conductance, } \\
\mu \mathrm{Sm} / \mathrm{cm}\end{array}$ \\
\hline 1 & $2.5 \pm 0.1$ & $11 \pm 3$ & $1.3 \pm 0.1(2.52 \pm 0.10)$ & $5 \pm 1$ \\
2 & $5.0 \pm 0.1$ & $21 \pm 3$ & $2.5 \pm 0.1(5.07 \pm 0.10)$ & $5 \pm 1$ \\
3 & $10.0 \pm 0.1$ & $40 \pm 3$ & $4.7 \pm 0.1(10.09 \pm 0.10)$ & $5 \pm 1$ \\
4 & $20.0 \pm 0.1$ & $73 \pm 3$ & $8.6 \pm 0.1(19.17 \pm 0.10)$ & $5 \pm 1$ \\
5 & $30.0 \pm 0.1$ & $112 \pm 3$ & $13.2 \pm 0.1(31.21 \pm 0.10)$ & $5 \pm 1$ \\
6 & $40.0 \pm 0.1$ & $144 \pm 3$ & $17.3 \pm 0.1(39.45 \pm 0.10)$ & $5 \pm 1$ \\
7 & $50.0 \pm 0.1$ & $181 \pm 3$ & $21.4 \pm 0.1(50.28 \pm 0.10)$ & $5 \pm 1$ \\
\hline
\end{tabular}

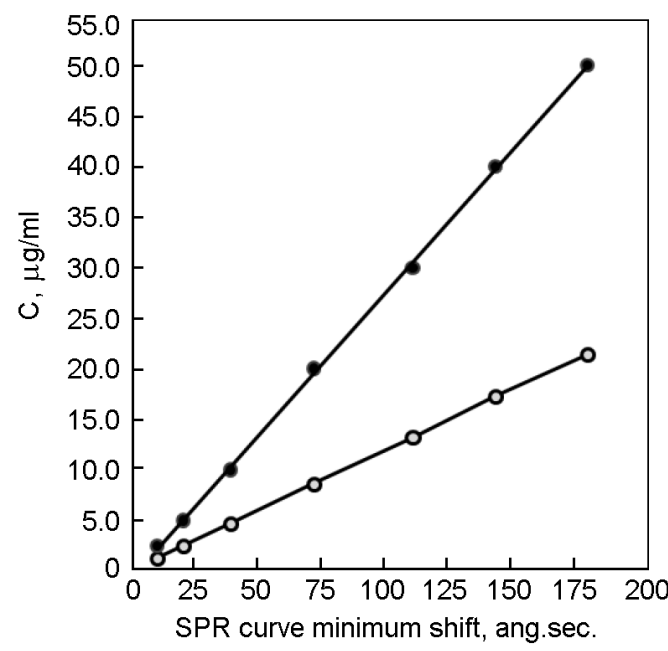

Fig. 2. Linear correlations between concentration of diamond powder in suspension and angular shift of reflection characteristic minimum under SPR conditions for experimental data (filled circles) and for those calculated using the model (open circles).

nano-sized diamond powder in suspensions (Fig. 2) has a linear character and can be approximated by function $y(x)=0.281 x-$ 0.808 with the matching factor $R^{2}=0.999$.

The observed difference between the experimental and theoretical results can be related to process of creation of conglomerates in suspension at longer distances from the sensitive element than that of surface plasmon field decay $(\lambda / 2.7=240 \mathrm{~nm})$. It can result in reducing the nanoparticles concentration in the sensitive zone and, as a consequence, to the reduced value of angular shift.

To estimate the difference between experimental and theoretical results, let us introduce a conglomeration coefficient $K_{\text {con }}$ defined as a ratio of concentrations calculated using formula (1) and those set experimentally. Our analysis shows that $K_{c o n}$

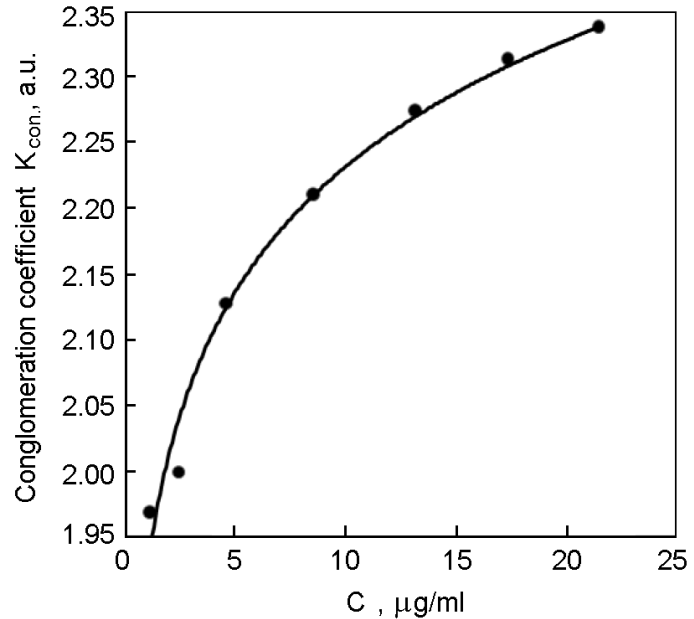

Fig. 3. Dependence of conglomeration coefficient $K_{c o n}$ on concentration of diamond powder in water suspension.

depends on concentration, and the plot of this dependence is well approximated by the logarithmic function $y=0.139 \cdot \ln (x)+1.909$ with the matching factor $R^{2}=0.984$ (Fig. 3). Thus, the conglomeration coefficient can be expressed via the concentration value (2).

$$
K_{c o n}\left(C_{t}\right)=0.139 \cdot \ln \left(C_{t}\right)+1.909,
$$

where $K_{c o n}$ - conglomeration coefficient; $C_{t}$ - calculated concentration of diamondwater suspension, $\mu \mathrm{g} / \mathrm{ml}$.

The relationship between concentration, calculated using the Maxwell-Garnett model, and the SPR sensor response is expressed by the linear plot (Fig. 2) that can be approximated by function $y(x)=0.119 \cdot x-0.011$ with the matching factor $R^{2}=0.999$. Substituting the approximation function into formula (2), one can obtain formula (3) for the conglomeration coefficient. 


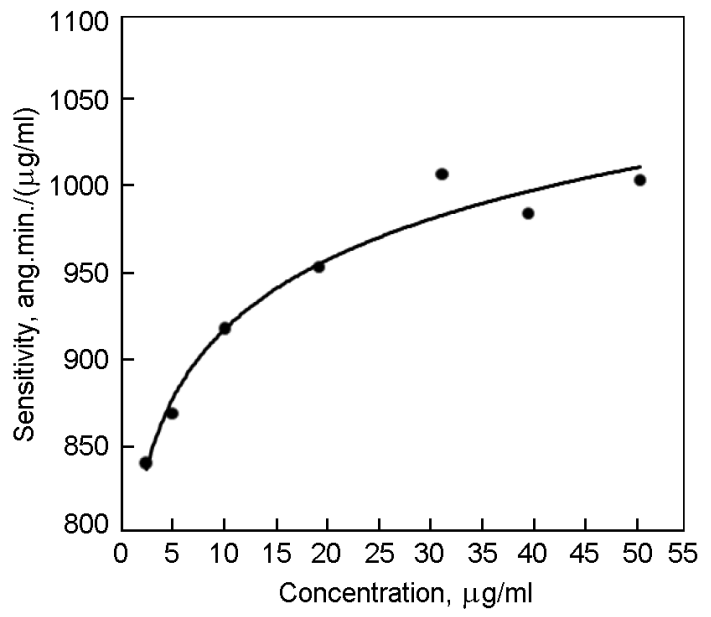

Fig. 4. Dependence of sensitivity of SPR sensor on concentration of diamond-water suspension.

$$
\begin{gathered}
K_{c o n}(\Delta \theta)= \\
=0.139 \cdot \ln (0.119 \cdot \Delta \theta-0.011)+1.909,
\end{gathered}
$$

where $K_{c o n}$ - conglomeration coefficient; $\Delta \theta$ - measured value of the SPR sensor response, ang. sec.

With account of formula (2), one can write the expression for calculation of the nanoparticle concentration in the suspension (4). The concentration values calculated using this expression are summarized in parentheses in Table 2.

$$
C(\Delta \theta)=(0.119 \cdot \Delta \theta-0.011) \cdot K_{c o n}(\Delta \theta),
$$

where $C$ is concentration of diamond-water suspension, $\mu \mathrm{g} / \mathrm{ml} ; K_{c o n}$ - conglomeration coefficient; $\Delta \theta-$ measured value of the SPR sensor response, ang. sec.

This expression enables to calculate the minimal concentration of filler in the matrix and sensitivity of the SPR refractometer (Fig. 4).

As the level of noise track in the signal measured with "Plasmon-6" is close to $\theta \Delta_{\text {noise }}= \pm 3$ ang. sec., then, for the signalto-noise ratio equal to unity, the minimal concentration of the filler in the matrix that can be measured by this device is $1.3 \mu \mathrm{g} / \mathrm{ml}$. The relative error of these measurements within the concentration range from 2 up to $50 \mu \mathrm{g} / \mathrm{ml}$ is less than $5 \%$, which is considerably less than the relative error of the conductometric method (20\%). With increasing the nanoparticles concentration in the suspension, the sensitivity of SPR sensor grows from
$840 \mathrm{up}$ to $1007 \mathrm{ang}$. $\mathrm{min} \cdot \mathrm{g}^{-1} \cdot \mathrm{ml}$, which is related with increasing the effective dielectric permittivity inside the area of surface plasmon decaying field [24].

\section{Conclusions}

It has been shown the capability to control the low concentrations of diamond powders in distilled water by using the method of surface plasmon resonance with the high sensitivity and accuracy. The SPR sensor sensitivity within the range of diamond nanoparticle concentrations in suspension between 2 and $50 \mu \mathrm{g} / \mathrm{ml}$ reaches the values from 840 up to $1007 \mathrm{ang}$. $\mathrm{min} \cdot \mathrm{g}^{-1} \cdot \mathrm{ml}$. The growth of sensitivity is related with increasing the effective dielectric permittivity within the area of surface plasmon decaying field, when the concentration of the nanoparticles is increased.

It has been offered the formula for calculation of the diamond nanoparticle concentration in water suspension by using the measured value of the SPR sensor response.

The relative error of the concentration value calculated according with this formula is less than $5 \%$.

The offered SPR method is express, since investigation of one sample does not exceed one minute.

The conductometric method is not informative, because in the range of the nanoparticle concentrations between 2 and $50 \mu \mathrm{g} / \mathrm{ml}$ the measured conductivity of suspension is the same: $5 \pm 1 \mu \mathrm{Sm} / \mathrm{cm}$. Consequently, it cannot be used to determine the low concentrations of indissoluble impurities in liquids.

\section{References}

1. A.Yu.Filatov, Rezaniye $i$ Instrument $v$ Tekhnologicheskikh Sistemakh, 85, 309 (2015).

2. J.C.Sung, J.Lin, Diamond Nanotechnology: Synthesis and Applications, Pan Stanford Publishing Pte Ltd., Singapore (2010).

3. V.Yu.Dolmatov, Nanotekhnika, 13, 56 (2008).

4. G.V.Sakovich, V.F.Komarov, Ye.A.Petrov, J. Superhard Mater., 3, 3 (2002).

5. Ye.V.Goncharuk, V.I.Zarko, V.M.Bogatyryov et al., Him. Fiz. Tehnol. Poverhni, 5, 210 (2014).

6. J.Aubin, M.Ferrando, V.Jiricny, Chem.Eng. Sci., 65, 2065 (2010).

7. H.G.Merkus, Particle Size Measurements: Fundamentals, Practice, Quality, Springer (2009).

8. V.M.Kutya, Bull. Engin. Acad. Ukraine, 3, 242 (2013).

9. O.Esteban, F.B.Naranjo, N.Diaz-Herrera et al., Sensor Actuat. B-Chem., 158, 372 (2011).

10. S.H.Yeom, O.G.Kim, B.H.Kanget et al., Opt. Express, 19, 22882 (2011). 
11. I.D.Voitovich, S.G.Korsunskyi, Sensors Based on Plasmon Resonance: Principles, Technologies, Applications, Stal, Kyiv (2011) [in Russian].

12. G.V.Dorozinsky, M.V.Lobanov, V.P.Maslov, East. Europ. J. Enterprise Techn, 4, 4 (2015).

13. N.Gridina, G.Dorozinsky, R.Khristosenkoet et al., Sensors and Transducers, 149, 60 (2013).

14. O.Wiener, Abhanl.Math-phys.Kl.Sachs.Wiss, 32, 509 (1912).

15. R.M.A.Azzam, Ellipsometry and Polarized Light, North-Holland, Amsterdam (1987).

16. J.M.Garnett, Philosophic Transact Royal Soc. London. Ser. A, Contain. Papers Mathemat. Phys. Character, 237 (1906).

17. V.D.Bruggeman, Ann.Phys-Leipzig, 7, 636 (1935).
18. G.V.Dorozinsky, V.P.Maslov, Yu.V.Ushenin, Sensor Devices Based on Surface Plasmon Resonance, Politekhnika (2016) [in Ukrainian].

19. S.Kedenburg, M.Vieweg, T.Gissiblet et al., Opt.Mat.Express, 2, 1588 (2012).

20. H.R.Phillip, E.A.Taft, Phys.Rev., 136, A1445 (1964).

21. E.Kretschmann, H.Raether, Z.Naturforsch., 123, 2135 (1968).

22. A.D.Rakic, A.B.Djurisic, J.M.Elazar et al., Appl.Opt., 37, 5271 (1998).

23. V.I.Chegel, Yu.M.Shirshov, S.O.Kostyukevich et al., Semicond. Phys., Quant. Electron. \& Optoelectron., 4, 301 (2001).

24. V.Yu.Plakhotnik, G.A.Polyakov, G.A.Dolinskii, Visnyk Sev NTU, 99, 82 (2009). 